\title{
National Policy and Identity under the Soviet Authorities in Uzbekistan in the 1920s and 1930s
}

\author{
BAHODIR PASILOV
}

\begin{abstract}
This article addresses the national policy of Soviet authorities in Uzbekistan in the 1920s and 1930s. It also studies the 'consolidation' of different tribes and ethnic groups in the process of establishing the national socialist republics and forming the 'socialist' nations and peoples within the framework of these states. The Soviet power considered the 'consolidation' of different tribes and ethnic groups as an important step in the construction of national socialist states. Certain tribes such as kipchaks, kurama, kongrats, mangits and others disappeared as a consequence of such consolidation. This article discusses how the national identification of 'socialist nations' was carried out by the introduction of 'socialist values' in the culture and life of local populations, different ethnic groups and tribes, which resulted in the dilution of self-identification as well.
\end{abstract}

Keywords: Soviet national policy, Uzbekistan, national identification, national minorities, ethnographic groups and tribes.

\section{Introduction}

Drastic changes took place in the political, social and economic spheres of Central Asia following the establishment of Soviet control in the period 1920 to 1930. Communism was introduced in Central Asia by force; the region was an unwilling participant in the Bolshevik socio-political experiment. Against the will of local communities, the geographic region was redefined to create specific nations. The purpose was to indoctrinate native populations with socialist ideology and create a Soviet state in the east. The newly founded Soviet national republics and autonomous regions 'were an essential step and necessary condition for reaching their main goal - building communism', as emphasized by the leaders of the Bolshevik party (I s'ezd Kommunisticheskoi partii (bolshevikov) Uzbekistana 1925: 23-24). 
Consequently, local populations experienced deep political, social and cultural transformations, which in turn had a strong impact on regional lifestyles, cultures and forms of territorial management. The consolidation of diverse peoples into a 'socialist nation' accelerated in this period and resulted in the loss of centuries-old traditions and customs. Many contemporary issues relating to the status and role of national minorities in the post-Soviet countries of Central Asia therefore have roots in this period.

It is important to mention that issues pertaining to Soviet national policy, nationality and the assimilation of ethnic Russians into indigenous populations across the Union of Soviet Socialist Republics (USSR), combined with the tensions among national minorities during the 1920s and 1930s in what today is the nation of Uzbekistan, constitute the focus of Soviet historiography on Central Asia. Unfortunately, this area of research is somewhat problematic due to the inherent biases of Soviet scholars, biases related to class and party categories. During the Soviet period, rigid ideological frameworks were deeply rooted in the historical sciences by political and educational authorities. Consequently, issues pertaining to Soviet national policy and the national-territorial delimitation of Central Asia, as well as related topics of minority political and social status and their respective interrelationships, were in essence characterized and synthesized from the perspective of Communist ideology.

These circumstances compel researchers such as myself to continuously investigate the problem of minority identity to review the issues from a contemporary historical perspective. Furthermore, many archival documents and sources, which were stamped 'secret' in the Soviet era, have since become accessible to researchers. New data in these sources enable scholars to better understand the essence of political and social processes to reinterpret events that occurred in the 1920s and 1930s.

In this article I examine the principal objectives of Bolshevik national policies in Central Asia and address the activities of the People's Commissariat on Nationality Issues, including local opposition to these policies and activities. Also examined are some of the major problems associated with national consolidation and identification as a way of shedding new light on current ethnic dynamics in Central Asia, especially in Uzbekistan. 


\section{Historical Background of the Region}

Central Asia can be considered one of the former spiritual and cultural centres of the world as well as Islamic civilization. The region included Uzbekistan, Kazakhstan, Turkmenistan, Tajikistan and Kyrgyzstan in Soviet historiography, but foreign scholars subsequently added Mongolia, northwest China, northern Afghanistan and northeast Iran to create a much larger regional construct. Such prominent figures as Avicenna, al-Beruniy, al-Farabiy, al-Ferghaniy, Alisher Navoiy, Ulugbek, Babur and others were born here and made substantial contributions to the development of medical science, astronomy, mathematics, philosophy and poetry.

The shifting and dynamic territories of ancient and medieval states such as Bactria, the Kushan Empire, Turk Khanat, Karakhanid state and Chingiz Khan's empire, were only partially employed in the formation of Soviet nations. One of the most powerful empires in world history, the region conquered and ruled by the great commander Temur in the second half of the fourteenth century, was responsible for the defeat of the Turk Sultan Bayazit and prevented the conquest of eastern Europe by the Ottoman Empire for half a century.

Three states, the Bukhara Emirate, and the Khiva and Kokand Khanates, were formed after the collapse of the Temur Empire and survived into the nineteenth century. Various national populations, including Uzbeks, Kazakhs, Kirghiz (Kazakhs are named in Russian sources as Kirghiz and later as Kara-Kirghiz), Turkmans, Tadjiks, Kara-Kalpaks, ethnic groups and tribes (e.g., sarts, qipchaks, mangits, qurama) and national minorities (e.g., Bukharan Jews, dzhugut, yahudi, Arabs, Persians, and the local Roma people known as luli) were combined in these states (Rossiya. Polnoe geograficheskoe opisanie nashego Otechestva 1913: 359-415).

However, Russian colonization led to essential changes in the geopolitical and ethnic configuration of the region: after liquidation of Kokand Khanate, the Turkestan general-governorship was formed in 1868, and later in 1882, was renamed as a Turkestan krai (region, land). The two other states, the Bukhara Emirate and the Khiva Khanate, were under the protectorate of tsarist Russia until the end of the nineteenth century. Thus, the people of Central Asia were also involved in the sphere of influence of tsarist Russian colonial policy.

To facilitate its expansion, the Russian government aspired to create strong social support in Central Asia. One consequence of this geopolitical task was the policy decision to create a reliable colonialist stratum among the 'hostile' native population by means of emigration (Pasilov 
1999: 159). Clearly, this policy resulted in the 'strengthening of the Russian element on the land' (Pereselencheskoe delo v Turkestanskon krae 1911: 331). In addition, many Russian peasants and other nationalities including Ukrainians, Belarussians, Germans and Jews voluntarily moved to Central Asia during this time to seek a better life.

As a result, in 1917 there were 330 Russian settlements with 16,257 courtyards in the Syr-Darya, Samarkand and Fergana regions of Turkestan (Tsentral'niy Gosudarstvenniy Arxiv Respubliki Uzbekistan (TsGA RUz): a). At the same time, refugees and immigrants (e.g., Uigurs, Dungans, Afghans and Iranians) from East Turkestan (modern Xinjiang-Uygur Autonomous Region of China), Afghanistan and Iran settled in this region as well. As sources testify, 14,556 individuals moved from Kashgar to Fergana in 1904, 13,337 in 1905, 25,056 in 1907, 12,725 in 1909, and 53,637 in 1911-12 (TsGA RUz: b). However, the Russian colonial administration imposed obstructive policies designed to complicate patterns of settlement among the new émigrés. The antagonism between Russian tsarist policy, local officials and the settled population created a number of problems that culminated in a mistrust of Russian officials. The above-described relationships in multi-ethnic Central Asia became an important backdrop to the Bolshevist revolution (October 1917) and had a profound impact on the development of Soviet power in the region.

\section{Turkestan Autonomy and Bolshevik National Policy in Central Asia}

The paradigm of great power, imperial thinking specific to the Russian Empire, became a core characteristic of the subsequent communist government of the Soviet state with the addition of the Marxist concept of 'proletarian internationalism'. The result of this combination of perspectives was the making of a 'Soviet people' (Pasilov 1999: 158-59) that effectively merged all nationalities in the creation of a super political community. The establishment of Soviet power in Turkestan during the first years of its existence did not lead to serious changes with regard to the socio-political conditions of local populations. From the first days of its existence, Soviet power aspired to solve ethnic issues inherited from the preceding Imperial government. In an address of the Soviet government to the people during this transition period, it was declared that Soviet power 'would provide the true right of self-determination to all nations which lived in Russia' (Lenin 1976a: 11). 
However, the right of self-determination for local nationalities, ethnic groups and national minorities, a crowning component of the Bolshevist national program, became conflated with 'the working class struggle for socialism'. As Lenin forcibly argued, the 'absolute recognition of the struggle for self-determination does not oblige us at all to support any requirement of national self-determination. We should always and, certainly, aspire to the closest connection of proletariat of all nationalities...' (Lenin 1976b: 233; emphasis added). As a result, the right of nations to self-determination amounted to nothing of consequence. Subsequent events that were to affect the socio-political life of Central Asia stand as compelling evidence of this fact.

On 15 November 1917, the Board of National Commissioners of the Russian Soviet Federal Socialist Republic (RSFSR) accepted the 'Declaration of the rights of the people of Russia'. In this resolution the main principles of Soviet national policy identified the equality and sovereignty of the people of Russia, the right of the people of Russia to free self-determination up to the formation of a separate and independent state, and the free development of national minorities and ethnic groups living in the territories of Russia.

Believing the false promises of the Bolsheviks, leaders of Central Asia's territorial regions met in Kokand in November 1917 to adopt a resolution at the IV Special Regional Muslim Congress. Leaders supported Bolshevik positions 'expressing the will of nationalities living in Turkestan to self-determination on the basis heralded by the great Russian revolution (Bolshevik Revolution of October 1917) declares Turkestan territorially independent in unity with the Federal Russian republic...'. And congress, as it was especially noted, further 'affirmed that the rights of national minorities living in Turkestan will be protected in every possible way' (Alimova and Radjabova 2000: 82-83). On 28 November 1917, the newly formed state was named Turkiston Mukhtoriyati (Turkestan Autonomy) (Alimova and Radjabova 2000: 83).

The structure of the provisional government of Turkiston Mukhtoriyati included people of different nationalities; in fact one out of three of the seats created in the new government was earmarked for national minorities, in particular for members of the local European population including Russians, Jews and Ukrainians. These included for example, the Prime Minister, the Minister of Internal Affairs (M. Tynyshpaev, Kazakh), the Prime Minister's deputy (Islam Sultan Shoakhmedov [Shagiakhmedov], Bashkir), the Military Minister (Ubaydulla Hodjayev, Uzbek), the Minister of Agriculture and Water Resources (Yurali Agayev, Tatar), 
the Minister of Food (Obidjon Makhmudov, Uzbek), and the Minister of Finance (Solomon Abramovich Gertsfeld [Gershfeld], Russian Jew), all members of the local European community.

However, later developments were to contradict the Bolshevist geopolitical interests in the East, which 'aspired to the closest connection of proletariat of all nationalities' under their command. Therefore soldiers of the Red Army, under the direction of Turkestan Bolsheviks, together with commandos of the Armenian nationalist party, Dashnaktsutyun, and under the direct instructions of the Bolshevist centre, cruelly routed Turkiston Mukhtoriyati. Despite broad support from the local Muslim population, the new state was quickly suppressed by force. Sources in this period described the events as follows:

Recently it (power) has sprinkled with human blood the Kokand's streets, has razed to the ground the old city occupied by Muslims, has ruined one thousand lives of unprotected Muslims, has plundered all their property ... not only under the usual banner, but under red, not with the usual slogan, but in the name of freedom and revolution (Noviy Turkestan 7 March 1918: 1).

The forcible suppression of Turkestan autonomy would culminate in an armed resistance to Soviet power, specifically the struggle of local populations in Central Asia for independence during the period 1918-33, with most activity occurring between 1918 and 1924 (Radjabov 2005: 50).

\section{Activity of the Turkomnats}

Following the defeat of the Turkiston Mukhtoriyati, the Bolshevist party found itself under time constraints as it was expected to meet the realization of the former Russian colony's right to self-determination while continuing to preserve the Soviet system of governance (administration). Moreover, as the Kokand events had shown, Bolsheviks faced the real threat of political isolation from local populations (Alimova and Radjabova 2000: 113).

As a result, from April 20 until 1 May 1918, the V Regional Congress of the Councils reinforced the principles of the Bolshevist program regarding the formation of 'Soviet autonomy' in Turkestan. On 30 April of that year, the Congress accepted the 'Statute of Turkestan Soviet Republic'. At the suggestion of the Bolsheviks, Turkestan became a Soviet republic of the Russian Soviet Federation and as such, would be governed independently and allowed coordination of its actions with the government of Russia (Alimova and Radjabova 2000: 115). 
Regional administrative agencies were created by the Congress, including their respective executive bodies, and referred to as the Council of National Commissioners. Considering the multinational structure of the population of Turkestan, a Commissariat of National Affairs was established (Agzamkhodjayev 2006: 256). Its departments were charged with the following responsibilities: organizing the political work among separate nationalities and protecting their interests in authorities, implementing the principles of Soviet power and the ideas of communism, eliminating ethnic frictions and continuing the struggle against displays of ethnic superiority (TsGA RUz: c). The first commissioner of the Turkestan Commissariat of National Affairs, (known as the Turkomnats), was Bolshevik T. Ashurhodjayev.

The activities of the Turkomnats were under the control of the National Commissariat of Affairs of Nationalities (RSFSR) and performed in accordance with the basic directions of the National Commissariat. Joseph Stalin defined the basic policy orientation of the Turkomnats during his tenure as head of the National Commissariat of Nationalities within RSFSR. The policies of the Turkomnats stated that all geographically peripheral Soviet authorities, their courts, administrations, economic organizations and bodies of direct power, must incorporate a majority of local peoples. This requirement was tacit recognition that indigenous representatives had firsthand familiarity with local ways of life, morals, manners and customs, and spoke the languages of local populations. Indeed, it was Stalin's intent to call on the best representatives in these bodies (Jizn'natsional'nostey 10 October 1920: 1).

Turkomnats's activities were strongly manipulated by the local Bolsheviks. Making matters worse, very few Bolshevik leaders spoke the native languages or were familiar with the customs of the peoples of Turkestan. Radical members of the Bolshevist government were inspired by the idea of world socialist revolution and opposed the existence of this body, and thereby ignored all locals. As a result, in September 1919, the VIII Regional Congress of Councils of Turkestan decided to liquidate the Turkomnats on the grounds that the existence of national commissariats 'contradicts international slogans' of Soviet power (TsGA RUz: d).

The decision of local leaders was subject to sharp criticism by the central Bolshevist government. The government comprehended the shortcomings of the decision to liquidate the Turkomnats and forced local heads to reconsider their relation to a commissariat of nationalities. Therefore, on 21 September 1921, the National Commissariat of National Affairs, consisting of the basic departments of Turkmen, Kirghiz 
(Kazakh), Uzbek, and minorities of other nationalities, was reinstituted (TsGA RUz: e).

On the whole, the Turkomnats worked effectively to establish closer relations between local peoples and European transplants, most notably the Russian population of the region. The decision of the Turkomnats to expand the use of regional languages was among the more important measures enacted. One positive result of the activity of the Turkomnats was the analysis of the national structure of various official bodies. From this analysis, the party and Soviet authorities made the decision to promote the elimination of inequality in the representation of different nationalities within governing bodies. As a report by the Turkomnats on 1 June 1922 testifies, in the Regional Commissariat of Food there were only four employees belonging to local nationalities among the 150 educated workers (TsGA RUz: f). And at the Public Health and State Publishing House Office there were no local nationalities represented among the 99 workers (TsGA RUz: g).

The Uzbek department under the Turkomnats actively engaged in education programmes for the local population. For example, through the efforts of this department, a group of Uzbek youths was sent abroad for training (TsGA RUz: h). The Turkomnats published the Ishtrakiyun (Communist), a newspaper that dedicated space to the reporting of various political and social problems in the local society. It was printed in Uzbek although a part of the circulation was in the Kazakh language as well (Makarova 1987: 81). Among other activities, the Turkomnats was also engaged in the reform of the Arabic alphabet and in Islamic studies.

Following formation of the USSR in 1922, and based on the recommendations of the Bolshevist government, the Turkomnats no longer served a purpose and the organization was abolished in May 1924.

\section{Formation of the Uzbek Soviet Republic: Consolidation and Formation of the 'Socialist Nation'}

Until the middle of the 1920s, it was possible to identify the three following states in Central Asia:

1. Turkestan Soviet Republic, which in 1920 was renamed the Turkestan Autonomous Soviet Socialist Republic (TASSR). State power within this republic was organized on the basis of the constitution of RSFSR and its native population was acknowledged as including Uzbeks, Kazakhs and Turkmans (Alimova and Radjabova 2000: 160); 
2. Bukhara People's Soviet Republic (BPSR), which was formed in 1921 after the overthrow of the Bukhara emirate; and

3. The Khorezm People's Soviet Republic (KhPSR) formed in 1920 after the Bolsheviks liquidated the Khiva khanate.

With regard to the previously described states, only TASSR may be characterized as subordinate to Soviet Russia, as the BPSR and KhPSR enjoyed the status of independent entities. However, both the BPSR and KhPSR were in practice also subordinate to the larger superstructure.

At the beginning of 1924, the Russian Bolshevist government considered the question of the existing national-territorial delimitation of the Turkestan, Bukhara and Khorezm republics. It is important to note here that the Bolshevist government presented delineation of these territories not as a national-territorial construct, but rather as the creation of nationstates. This review was undertaken to show that Bolsheviks were defenders of the formation of independent Soviet states in Central Asia.

In 1920, the Bolsheviks first considered a regional division of land according to the geographic location of ethnic groups. Subsequently they discussed the question of the formation of national republics such as Turkman, Uzbek and Kirghiz (Alimova and Radjabova 2000: 158). However, Lenin, then leader of the Bolsheviks, did not force recognition of these territories but suggested making a preliminary map of Turkestan (to include ethnographic, economic and other information), Uzbekiya, Kirghizia (i.e., Kazakh), and Turkmeniya and to document in detail the conditions warranting merger or division into three parts (Lenin 1977: 435-36).

Thus, in 1920 the idea of creating a Turkestan republic as part of the Russian Soviet Federation was transformed into a major task since, at that time, the Bukhara and Khorezm republics were operating independently. Also, two autonomous regions, Kara-Kirgiz and Tadjik (Vareykis and Zelenskiy 1924: 46), were under consideration for designation as independent republics.

The Central Territorial Commission on National Delimitation of Central Asia, or CC RKP (b) was created as an agency under Sredazburo (the Central Asian bureau). Its main task was to carry out a program of national territorial reorganization. Organized under this commission were Uzbek, Turkmen, Kirghiz and Kazakh provisional national bureaus on delimitation of Central Asian republics. Also created at this time were the Tadjik and Kara-Kalpak national subcommittees (Arkhiv Apparata Prezidenta Respubliki Uzbekistan). But even before creation of these national bureaus and subcommittees, preparatory studies were 
conducted to determine the size and national structure of local populations, economic relations among these regions and key economic and household features of the various regions. The census information obtained on the districts of Turkestan and new administrative divisions of Bukhara and Khorezm provided the initial data used to delineate the territories of the new Soviet republics and autonomous regions of Central Asia.

It was discovered during the census of 1920 that the majority of Uzbeks referred to themselves as Uzbeks. Yet large numbers of Uzbeks also referred to themselves using old tribal names. Of 89,364 Uzbeks in the Djizak uyezd of the Samarkand area, 66,886, or more than 75 per cent, were registered as 'Uzbek', with the remaining number listed by tribal and generic names (djalair, mitan, nayman, bagrin) (Materiali Vserossiyskoi perepisi 1924: 35-36).

During the study known as rayonirovaniya (the division of territory into national and regional districts) conducted by the Soviets in 1924-26, it was revealed that in Khorezm, Uzbeks who had mainly settled in the southeast part of the Khiva oasis did not remember old generic and tribal relations and referred to themselves as Uzbeks. However, the population residing on the opposite (left) bank of the Amu Darya River and northwest part of the oasis still remembered their tribal names (Materiali po rayonirovaniyu Sredney Azii.Kn.2. Territoriya i naselenie Bukhari i Khorezma. Chast 2. Khorezm 1926: 96). As a result of this study, the rayonirovaniya commission defined the tribes and population numbers represented among the Khorezm Uzbeks, including the following: 7,600 qungrats, 10,300 mangyts, 1,700 durmens, and 1,300 ktays (khtays) (Materiali po rayonirovaniyu Sredney Azii.Kn.2. Territoriya i naselenie Bukhari i Khorezma. Chast 2. Khorezm 1926: 98-102).

As a whole, the native population of Khorezm consisted almost exclusively of Turkic peoples. The Iranian element (Persians) was insignificant in size, consisting of only 1,419 individuals. Uzbeks enjoyed a large numerical superiority over other Turkic-speaking groups as they comprised 79.5 per cent of the total population. Second in size were Turkmans at 14.5 per cent, followed by Kazakhs at 4.3 per cent. Other Turkic groups, including Kara-Kalpak and Tatars ('nogai' as they were known in Khorezm), were small in number (Materiali po rayonirovaniyu Sredney Azii. Kn. 2. Territoriya i naselenie Bukhari i Khorezma. Chast 2. Khorezm 1926: 89-90).

Arabs also lived in Khorezm as did Persians who were descendants of the Arab conquerors. German Mennonites moved to Turkestan in the 
1870s from the Saratov province of Russia following a request by the Russian General Kaufman for development of new agricultural lands (Materiali po rayonirovaniyu Sredney Azii. Kn. 2. Territoriya i naselenie Bukhari i Khorezma. Chast 2. Khorezm 1926: 93-94).

The native population of the Bukhara republic was divided among three groups: 1) Turkic, consisting of approximately 978,000 people (63.9 per cent of the total population) and comprised of Uzbeks, Turkmans and Kazakhs (the last are small in number); 2) Iranian, including Tadjiks and small groups of Persians and Afghans, consisting of about 484,000 people (31.6 per cent); and 3) Semitic, comprised of Arabs and Bukharan Jews, including approximately 54,000 people (3.5 per cent) (Materiali po rayonirovaniyu Sredney Azii. Kn I. Territoriya i naselenie Bukhari i Khorezma. Chast I. Bukhara 1926: 164). The Russian population was registered only in certain cities and did not exceed more than about 12,000 people $(0.8$ per cent of the total population). Other minority nationalities consisted of less than 3,000 people (0.2 per cent) with Armenians comprising half of this number (Materiali po rayonirovaniyu Sredney Azii. Kn I. Territoriya i naselenie Bukhari i Khorezma. Chast I. Bukhara 1926: 164).

Census data indicate that a considerable number of Uzbeks in Bukhara did not remember their old tribal and generic names but simply recognized themselves as Uzbeks. However, as was the case in Khorezm, many other 'Uzbeks' also continued to recognize old tribal names, including qipchak, nayman, Turkis, mangyt, qungrat, qatagan, keneges, and loqay, among others (Materiali po rayonirovaniyu Sredney Azii. Kn I. Territoriya i naselenie Bukhari i Khorezma. Chast I. Bukhara 1926: 174-223).

Turkmans comprised the second largest number represented among the population of Bukhara. As noted above, the generic and tribal divisions among Turkmans remained very strong. Indeed, the most numerous group among the Turkman population of Bukhara was the tribal group ersari. Ersari made up fully 57.5 per cent of the Turkman population. Almost all of the major Turkman tribes were represented in this region, except for the tekin (Materiali po rayonirovaniyu Sredney Azii. Kn I.Territoriya i naselenie Bukhari i Khorezma. Chast I. Bukhara 1926: 235-43).

The Soviet administrators, who argued for the necessity of national territorial delimitation, also emphasized that

this was of particular importance for Turkman. The development of a Turkman nation was historically hampered by the struggle of conflicting tribes over oases and pastures. Although the development of the Turkman 
state accelerated the process of nation formation, unification was at the expense of the destruction of the tribal (aul) way of life (Vareykis and Zelenskiy 1924: 59-60).

The territorial commission, along with other commissions on national-territorial restructuring, decided that ethnic names and groupings should take into account local naming of the territory, economic life among the locals, language and culture, and finally, a general tendency towards national consolidation.

Accordingly, the part of the population of the Tashkent District (uyezd) (Turkestan republic), living in the valley of the Angren River, named itself qurama. According to the census figures there were 49,700 members of this group in 1920. The ethnographic group qurama ('a mix') formed as a result of the mixing of Uzbeks and Kazakhs (K probleme natsional'nogo razmejevaniya Sredney Azii 1924: 40). Some sources indicate that the qurama were not cognizant of their nationality. However, there seems to be a desire among them to avoid the term qurama or to interpret it as a secondary definition. For example, about 500 people among the population of three villages of Babadarhan volost (province) within the Namangan uyezd are descendants of natives from the qurama village Telau, today refer to themselves as Uzbeks, Turks and even Tadjiks (Zarubin 1925: 12).

Leaders of the Khorezm republic were actively against national-territorial delimitation, a position considered by the Bolshevist government as a display of Uzbek superiority. Leaders of the Executive Bureau of the Central Committee of the Khorezm Communist Party were called 'hostile elements' and 'bourgeois nationalists'. Despite the resistance of the local political elite, the Bolshevist government of Central Asia managed to persuade the leaders of Turkestan, Bukhara and Khorezm to agree on the territorial division of Central Asia based on the distribution of regional ethnic majorities.

Afterwards, implementation of the Soviet policy of national delimitation in Central Asia was started. This agreement ushered in the period of practical implementation of national delimitation of Central Asia. In October 1924 the following republics were formed in the place of the former Turkestan, Bukhara and Khorezm Soviet Republics: the Uzbek Soviet Socialist Republic (UzSSR), Turkmen Soviet Socialist Republic (TSSR) and Tadjik Autonomous Soviet Socialist Republic, which entered into the structure of UzSSR. Other new 'states' such as the KaraKirghiz (Kirghiz) and Kara-Kalpak Autonomous Regions entered into the structure of the Russian Federation and the Kazakh Autonomous 
Republics accordingly (Tursunov 1957: 152-53). The UzSSR and TSSR announced their 'voluntary' union with the USSR. On 13 May 1925, the III Congress of Councils of the USSR recognized the 'free will of the people' in the Turkman and Uzbek republics in their decision to join the USSR (Alimova and Radjabova 2000: 666).

The constitution of the Uzbek Soviet Socialist Republic proclaimed the equality of all nationalities and declared the establishment or assumption of any privileges or advantages for separate nationalities as contradicting the laws of the republic. It also did not support the restriction of rights among national minorities of the republic. The formation of the Soviet national republics initiated an important stage in the history of the people of Central Asia. Specifically, their formation produced the inclusive transformational processes that fundamentally altered the mentality, culture and traditions of native and minority populations across the region.

National boundary restructuring and the formation of national Soviet republics destroyed the tribal way of life of nomadic people in this region. In this regard, the Kazakhs, Kirghiz, Kara-Kalpak and Turkman groups who possessed a strong patrilineal orientation in the pre-Soviet period, gradually became part of a unified nation. Although patrimonial divisions gradually became less important than national identity, these divisions still play an important role in the socio-political life of group members.

Thus, the realignment of national-territorial boundaries, despite its problems and related social unrest, represents a decisive stage in the national consolidation of the people of Central Asia, including the Uzbek nation. According to Soviet theorists, Soviet state formations, unions and autonomous republics, autonomous regions, and the national districts united in the uniform multinational Soviet state. Thus, the USSR represents a reasonable form of state, one which provides to all the development of 'socialist nations' (Tursunov 1957; Kozlov 1954; Leninizm i natsional'niy vopros v sovremennykh usloviyakh 1974).

Despite the negative consequences of Bolshevik national policy in the region and the serious errors committed by the Bolsheviks in the course of carrying out the redesign of national boundaries, Uzbeks, Kazakhs, Turkmans, Tadjiks, Kara-Kalpaks and Kirghiz were able to develop and contribute to studies of the humanities and sciences, albeit under the strict control of Moscow. However, the role played by ethnic Russians and their language in all national Soviet republics was defining in every respect. Soviet political leadership and its ideologues attributed many 
achievements of regional populations to the Russians themselves, who 'helped to construct socialism and to create a working class among all nationalities of Central Asia'. In the coming decades, Russians occupied an exclusive position in the consciousness of all nationalities. Russians were deemed 'big brother' by peoples throughout the region. We can describe this period as a type of 'restart', whereby the Bolsheviks tried to improve the relationships between Russians and the native groups that lived in the former Russian colonies.

The creation of 'socialist nations' led to a levelling of generic and tribal divisions, including the many divisions of Uzbek people. Many tribes and ethnographic groups such as the qipchak, nayman, mangit, qungrat, qatagan, keneges, logay and qurama, among others, were consolidated with the formation of the Uzbek nation.

\section{National Minorities and the Paradigm of Soviet National Politics in Uzbekistan}

Soviet national policy with respect to national minorities living in the Turkestan republics was constructed around the designs of the Bolshevist national programmes. After the inclusion of the Bukhara and Khorezm Soviet republics in the sphere of Bolshevist interests, their leaders also strived for the unification of national policy in accordance with the stated positions of the Bolsheviks. These republics also contained the largest number of different nationalities. According to the census of 1926, the Uzbek Soviet Socialist Republic included the following ethnic/national divisions: 28,000 Tatars, 28,000 Arabs, 25,000 Ukrainians, 20,000 Jews and 15,000 Armenians, in addition to other groups (Vsesoyuznaya perepis'naseleniya 1926 goda 1926: 8-9).

I described earlier the role of the Turkomnats and its department of national minorities in the revision of regional settlement and the lifeways of national minorities. From analysis of the activities of the heads of departments, it is clear that little attention was paid to the protection of individual rights and freedoms among these national minorities (TsGA RUz: i). Instead, the Turkomnats and its departments studied the conditions of national minorities and reported on various aspects of the lifeways of these and other national groups in informative reports. After the Bolsheviks came to power in October 1917, a newspaper entitled Jizn'natsional'nostey (Life of Nationalities) was published and was intended to provide generalized information on the lifestyles and problems of national minorities under headings such as 'Armenians of 
Turkestan' (TsGA RUz: j), 'Ukrainians of Turkestan', (Jizn'natsional' nostey 11 September 1922: 1) and 'The review of the condition of the German population in the Turk republic' (TsGA RUz: k).

The attention given to the interests and requirements of national minorities resulted in the creation of the Council of Affairs of National Minorities under the National Commissariat of Education of Turkestan Autonomous Soviet Socialist Republic (TASSR). This body was called to study, first of all, the spiritual needs of national minorities and to undertake practical actions toward meeting their particular needs. The following minority divisions were recognized in 1920: Armenian, Iran-Azerbaijan, native Jewish, Ukrainian, Tatar-Bashkir, German and European Jewish.

The Committee of Affairs of National Minorities was created after the formation of the Uzbek Soviet Socialist Republic (UzSSR) in December 1924. It was soon renamed the Central Commission of Affairs of National Minorities under the Central Executive Committee (CEC) of the Councils of UzSSR (Pravda Vostoka 22 December 1924: 2). Independent administrative units were created in the form of special regions with the active participation of the Commission of Affairs of National Minorities in Uzbekistan. These included Kanimekh, mainly populated by Kazakhs and Kara-Kalpaks, and the Kanibadam District of the Fergana region with a majority Tadjik population (TsGA RUz: 1).

From the first years of its existence, the Soviet government aimed to involve national minorities in the process of building socialism and to introduce socialist values into the consciousness of the peoples of Central Asia. Development in terms of 'class', national self-consciousness, and satisfaction of cultural-educational and spiritual needs were also important parts of Soviet 're-education' of national minorities. Uigurs, Tatars, Bashkirs and Azerbaijanis who were related to the people of Central Asia through language and culture were also included in this re-education process. Following are brief synopses of these minority groups.

\section{The Tatars}

The Tatars appeared as permanent residents in the territory of Central Asia at the end of the eighteenth and beginning of the nineteenth centuries. Many young Tatars came to study at the Bukhara madrasah in this period. Newspapers and magazines in the Tatar language were published as early as 1920 and there were national libraries and professional theatres and the institute of education prepared teachers for the Tatar schools. There was even a Tatar section of the organization of writers and it included several writers at this time (Shigabdinov and 
Jukova 2002: 203-05). There were also 17 national schools, three preschool institutions and two libraries that functioned under the guidance of the Tatar-Bashkir Bureau in Uzbekistan beginning in the second half of 1920. In addition, two Tatar collective farms were created in 1929 (Shigabdinov and Jukova 2002: 203-05).

\section{The Armenians}

Armenians were well represented among the Central Asia national minorities who actively aspired to unification, development of their language and preservation of cultural traditions. The history of their immigration to Central Asia is connected with the various political and economic events associated with the resettlement of thousands of Armenians in Turkestan, particularly at the beginning of the twentieth century. The largest number of immigrants settled in cities such as Tashkent, Samarkand, Ashkhabad, Kokand and Andijhan (Amir'yants and Grigor'yants 1992: 164). In contrast to the Jews who resettled here from Russia, Armenians found support from the Russian colonial administration of Turkestan.

Cultural and educational centres for Armenians, or the so-called working houses, were created in May 1919, to promote the development of art, dancing and musical collectives. Thus, by the beginning of 1920 efforts were in place to introduce European arts to national minorities including Armenians. The Armenian Central Bureau organized 30 concerts and parties from January through March 1923 in these working houses. Six lectures were presented and the earnings generated were used to benefit poor Armenian students and for the maintenance of the working house where these talks took place. There were ten Armenian schools during this period in the Turkestan Republic and some were able to obtain textbooks in the Armenian language (TsGA RUz: m). We also note the presence of an Armenian theatre named after Shaumyan in Tashkent by 1930 . Here young, enthusiastic artists performed contemporary as well as classical theatre programmes. In 1937, the theatre was transformed by the decision of the Soviet government into the Armenian club, hosting essentially Armenian cultural performances (Amir'yants and Grigor'yants 1992: 169-70).

\section{The Bukharan Jews}

Soviet administrators paid attention as well to the problems of Jews, in particular Central Asian (Bukharan) Jews. Central Asian Jews concentrated in the Bukhara Emirate were ranked as Gentiles. They were 
allowed to practice their religion and to own property, but in criminal matters and for transactions involving Muslims they had to follow Islamic laws (Nazar'yan and Nekrasova 2002: 91). During the Russian colonial period the legal inequality imposed on Central Asian Jews was softened. Jews were allowed to buy houses and to settle in a new part of Samarkand as well as in other cities.

By the last third of the nineteenth century, the term 'Bukhara Jew' appears in official Russian documents. Central Asian Jews who were citizens of the Bukhara Emirate were given this designation while Jews who were formerly citizens of Russia and living within the territory of Turkestan were referred to as 'native Jews'. With the coming of Soviet power, liquidation of the Bukhara Emirate, and the national-territorial delimitation of Central Asia, the term 'Bukhara (later Bukharan) Jew' became the general term applied to all local Jews irrespective of their places of residence (Nazar'yan and Nekrasova 2002: 91).

Recognition of the unequal social and political status of native Jews forced the Soviet authorities to pay more attention to their requirements. Therefore, it was decreed that Bukhara Jews in Central Asia be considered part of the native population and be given access to all the privileges granted majority groups within the Uzbek Republic (TsGA RUz: $n$ ). As noted above, a native Jewish department had been created in the Turkomnats, and a special section designating national education for native Jews was created through the National Commissariat of Education. In September 1919, a school for Bukhara Jews and some kindergartens were opened as a result of this initiative (TsGA RUz: o).

In August 1924, the Central Executive Committee (CEC) of the USSR decided to implement actions to attract the Jews to agricultural work as most had traditionally engaged in trade and business. Following this decision, a movement developed to encourage agricultural work among the Jewish population. Despite the legislative authorization for the transition of Bukhara Jews to agricultural work, local authorities interfered with the allocation of land for this purpose for many years to come. For example, the National Commissariat of Land Tenure published a decree allocating 537 dessiatinas (1 desytina is 1,09 hectares) of land for development but the land department of the Syr-Darya region interfered with the implementation of this decree in every manner possible (TsGA RUz: p).

One result of this resistance to development involving the Jewish population was the expansion of organized agricultural associations beginning in 1920. These organizations worked to unite workers assigned to 
collective farms responsible for gardening, vegetable growing and cotton production, among other agricultural products. There were 63 farms in 1926 and these were combined into 26 Jewish collective farms by 1929 . The number of farms grew to 279 in 1930 and 425 by 1932 . There were 15 collective farms encompassing 894 farmers in 1937, the largest of which were in the Samarkand District. Clubs, libraries, polyclinics and schools with Jewish-Uzbek and Jewish-Tadjik language training also were developed as part of these collective farms (Nazar'yan and Nekrasova 2002: 94). Among the institutions founded for the promotion of culture and education were the Jewish pedagogical institute, ten schools, four preschool centres, three boarding schools and three libraries, all developed in the period after 1920 (Nazar'yan and Nekrasova 2002: 94).

Minority groups were given the right to assemble and resulting meetings were effective in problem solving and supporting the developing relationships between various national minorities. Meetings were often held when urgent problems appeared and representatives were able to offer their opinions and decisions were made democratically. These meetings were convened in 1928, 1932 and 1935. Representatives of national minorities were permitted to speak in their native languages at these meetings, except for Uzbek and Russian attendees (TsGA RUz: q).

Soviet administrators in the national republics introduced the policy of korenizatsiya ('nationalization') in the mid-1920s. It was a complex set of special state actions that included the preparation of national cadres, the translation of office work into local languages and the involvement of 'working masses' of various nationalities in the state building projects. This policy dates to the first half of the 1920s when individuals of Russian and European descent dominated the administrative and party bodies of national republics. Most did not speak local languages and lacked even elementary understandings of local traditions and culture. In general, the participation of native groups in these bodies up to this time was insignificant. This policy was intended to remedy that problem.

Therefore, as some Soviet theorists noted at the time, the policy of korenizatsiya had the purpose of expanding the state machine through the addition of representatives, both Russian and other ethnicities, including those from the smallest national communities. In this way the Soviets aspired to protect the interests of local people and to transform the state machine to hear the concerns of the 'working masses' (Khakimov 1965: 385). Positive results appeared at the initial stage in the implementation of the policy of korenizatsiya. In the period from 1924 
through January 1927, the number of Uzbek workers represented in the central authorities increased 2.5 times all over Uzbekistan. In practice, the Tadjik, Kazakh and Kara-Kalpak populations of Uzbekistan had the opportunity to participate in the management of the national districts, and their national languages, as well as Uzbek, received the status of state languages.

The structure of the state and administrative bodies consisted of representatives of different national minorities. For example, the structure of the Yangiyul (Tashkent region) executive committee consisted of Tadjiks, Uigurs, Iranians and Tatars, groups that when combined comprised 3 per cent of the population of this district (Khakimov 1965: 396-97).

However, other tendencies in the national policies of the Soviets pertaining to national minorities, especially those nationalities not represented in the Soviet Union, became apparent (Vdovin 2002: 41). It was at this time that the policy of deportation of 'unreliable' national minorities began. The 'cleanup' of the frontier strip around the Soviet Union was pursued and given a military justification. Individuals from ethnic groups well represented in neighbouring countries were deemed unreliable and deported. In April 1936, the Council of People's Commissioners (CPC) in the USSR made the decision to resettle 15,000 families (45,000 people) of Polish and German descent from Ukraine to what today is Kazakhstan. In 1937, 172,000 Koreans, several hundred Poles and 11,000 Chinese were deported from areas of the Far East to Uzbekistan and Kazakhstan. Of this number, 16,307 families $(98,454$ people) settled in Uzbekistan (Vdovin 2002: 41). Thus, Koreans became one of the most recent ethnic additions to the multi-ethnic structure of Uzbekistan. Between 1938 and 1939, Korean and mixed-Korean schools were created in those areas of Uzbekistan where Koreans were densely settled. In this period the total number of Korean and Korean-mixed schools was 96. The total number of Korean students attending was 19,980 (Djarilgasinova 1992: 62).

In 1930, the USSR introduced a policy designed to expand the use of Russian language among Central Asians including all national minorities. This policy was contained in the resolution 'On compulsory learning of Russian language at schools of national Republics and regions'. A similar resolution was adopted in all Soviet Republics between March and April of 1930 (Vdovin 2002: 46). This resolution compelled Russian language training in all non-Russian elementary schools from the second class onward and in all secondary schools from the third class of training. Soviet administrators explained this policy by maintaining 
that obligatory teaching of Russian at non-Russian schools meant that it 'became the international language of socialist culture' (Vdovin 2002: 47). As a consequence, the social function of Russian language training gained importance in the socio-political life of people included within the sphere of the Soviet Union and this included national minorities. In time this policy dramatically reduced the use of national languages among local populations.

Despite the negative tendencies embedded in Soviet national policy, the national minorities of Uzbekistan managed, despite the pervasive oppression of Communist ideology, to make important progress in the development of new social and political skills during the first half of the twentieth century. The very policies designed to control these groups in fact played an important role in overcoming illiteracy and paved the way for the emergence of national cadres and political elites.

\section{Conclusion}

The analysis presented here allows the following conclusions concerning Soviet national policy and the impact of policy changes on the socio-political and cultural life of diverse ethnic groups and national minorities in Central Asia during the first half of the twentieth century.

First, following the overthrow of tsarism and the establishment of Soviet power, Bolsheviks strived to retain the territory of the former Russian Empire, placing it fully within the operations of Soviet Russia. The idea of self-determination for ethnic minorities, one of the fundamental principles of the Bolshevist's national program, became an empty promise. Ultimately, the efforts of many Central Asians to gain independence by declaring the autonomy of Turkistan were severely suppressed by the emerging Soviet power.

Second, national minorities in this region were pulled into the orbit of Soviet Empire policy. As a result, Central Asia became a 'testing ground' for the building of socialism across the east. In order to implement their geopolitical goals, the Bolshevists pursued a strict geographic restructuring of Central Asian territories. Accordingly, the formation of Central Asian Soviet Republics occurred within essentially the same socio-political framework established for the creation of 'socialist nations' within the Soviet sphere of influence. Many native Central Asians in this era were left to live outside their identified national republics and thus became national minorities or in some cases, diaspora populations.

Third, the formation of the National Soviet Republics ushered in a 
new era of relations between the empire nation (Russia) and indigenous peoples within the former Russian colonies of Central Asia. Although Soviet law sanctioned the equality of all people in the USSR, in practice such policies were revised by regional Soviet administrations. And as a result of revisions in policy, Russian language and education increasingly became oppressive forces of change in the National Soviet Republics. In time, the notion of Russians as the 'elder brothers' of the various ethnic groups in Central Asia spread and ultimately was inculcated in the consciousness of native people and national minorities alike.

Bahodir Pasilov is currently Senior Research Fellow in the Department of Socio-Political History of Uzbekistan (19-20 th centuries), at the Institute of History of the Academy of Sciences of Uzbekistan.

\section{REFERENCES}

I s'ezd Kommunisticheskoi partii (bolshevikov) Uzbekistana. Stenograficheskii otchet 1925. (1st Congress of the Communist party (Bolsheviks) of Uzbekistan. Verbatim report). Tashkent.

Agzamkhodjayev, Saidakbar. 2006. Istoriya Turkestanskoy avtonomii (Turkiston mukhtoriyati). (The history of Turkestan autonomy). Tashkent: Tashkent Islam University.

Alimova, D., and R. Y. Radjabova, (eds.). 2000. Turkestan v nachale XX veka: $k$ istorii istokov natsionalnoy nezavisimosti. (Turkestan at the beginning of the $20^{\text {th }}$ century: to the history of the origin of national independence). Tashkent: Sharq.

Amir'yants, I. A., and I. A. Grigor'yants. 1992. 'Armyane Sredney Azii'. In A. N. Jilina and S. V. Cheshko (eds.), Sovremennoe razvitie etnicheskix grupp Sredney Azii i Kazakhstana. (Modern development of ethnic groups in Central Asia and Kazakhstan), Part 1. Moscow: Institut etnologii i antropologii im. N.N. Miklukho-Maklaya.

Arkhiv Apparata Prezidenta Respubliki Uzbekistan (AAP RUz) (Archive under the Office of the President of Uzbekistan). Fond 62, opis 1, delo 152, list 71.

Djarilgasinova, R.S. 1992. 'Etnokulturnoe razvitie koreitsev Srednei azii I Kazakhstana'. (Ethno cultural development of Koreans of Central Asia and Kazakhstan). In A. N. Jilina, S. V. Cheshko (eds.), Sovremennoe razvitie etnicheskix grupp Sredney Azii i Kazakhstana. (Modern development of ethnic groups in Central Asia and Kazakhstan), Part 1. Moscow: Institut etnologii i antropologii im. N.N. Miklukho-Maklaya.

Jizn' natsional'nostey. (The Life of Nationalities). 1920, 10 October.

- 1922, 11 September.

K probleme natsional' nogo razmejevaniya Sredney Azii (istoriko-etnograficheskiy ocherk). (On the problem of national delimitation of Central Asia (historical and ethnographic outline). 1924: nos. 2-3. Moscow: Narodnoe khozyaystvo.

Khakimov, M. Kh. 1965. Razvitie natsional'noy sovetskoy gosudarstvennosti v Uzbekistane $v$ period perekhoda $k$ sotsializmu. Osnovnye problem. (Development of nationalities of the Soviet statehood in Uzbekistan during the transition period to socialism. The main problems). Tashkent: Nauka (Science).

Kozlov, V. K. 1954. O formirovanii i razvitii sotsialisticheskix natsiy $v$ SSSR. (Formation and development of socialist nations in USSR). Moscow: Gosudarstvennoe izdatelstvo 
politicheskoi literaturi.

Lenin, V.I. 1976a. Polnoe sobranie sochineniy. (Complete works), vol. 35. Moscow: Politizdat.

- 1976b. Polnoe sobranie sochineniy. (Complete works), vol. 7. Moscow: Politizdat.

- 1977. Polnoe sobranie sochineniy. (Complete works), vol. 41. Moscow: Politizdat.

Leninizm i natsional'niy vopros v sovremennykh usloviyakh. Izd. 2-oe. (Leninism and the national issue in the present day. Second edition). 1974. Moscow: Nauka (Science).

Makarova, G. P. 1987. Narodniy komissariat po delam natsional' nostey RSFSR. 1917-1923. Istoricheskii ocherk. (People's Commissariat for issues of nationalities of RSFSR. 1917-1923. Historical essays). Moscow: Nauka (Science).

Materiali po rayonirovaniyu Sredney Azii.Kn I. Territoriya i naselenie Bukhari i Khorezma. Chast I. Bukhara. (Materials on regionalization of Central Asia. Book 1, Territory and population of Bukhara and Khorezm. Part 1. Bukhara). 1926. Tashkent: Izd. Komissii po rayonirovaniyu Srednei Azii.

Materiali po rayonirovaniyu Sredney Azii.Kn. 2. Territoriya i naselenie Bukhari i Khorezma. Chast 2. Khorezm. (Materials on regionalization in Central Asia. Book 2, Territory and population of Bukhara and Khorezm. Part 2. Khorezm). 1926. Tashkent: Izd. Komissii po rayonirovaniyu Srednei Azii.

Materiali Vserossiyskoi perepisi. Perepis' naseleniya $v$ Turkestanskoi respublike. Vip. V. (Materials of All-Russian census. Census of population in Turkestan Republic, Issue 5). 1924. Tashkent.

Nazar'yan R., and E. G. Nekrasova. 2002. 'Evrei sredneaziatskie'. (Central Asian Jews). In A. Ilkhamov (ed.), Etnicheskii atlas Uzbekistana. (Ethnic atlas of Uzbekistan). Istanbul: Open Society Institute Assistance Foundation Uzbekistan.

Noviy Turkestan. (New Turkestan). 1918, 7 March.

Pasilov, B. 1999. 'Kolonial'niy kharakter migratsionnoi politiki sovetskogo totalitarnogo rejima'. (Colonial character of migration policy of the Soviet totalitarian regime). In D. Alimova (ed.), O'zbekiston tarikhining dolzarb muammolariga yangi chizgilar. Davriy tuplam. № 2. (New strokes to the urgent issues of the history of Uzbekistan. Periodical issue no. 2). Tashkent: Sharq.

Pereselencheskoe delo $v$ Turkestanskon krae (oblasti Syrdar'inskaya, Samarkandskaya $i$ Ferganskaya). Otchyot po slujebnoy poezdke v Turkestan osen'yu 1910 goda chinovnika osobykh porucheniy pri Pereselencheskom upravlenii N.Gavrilova. (Migration in Turkestan (Sirdarya, Samarkand, Ferghana regions). Report of N.Gavrilova, official-at-large under the Migration Department about his business trip to Turkestan in autumn 1910, 1911). 1911. S-Peterburg.

Pravda Vostoka. 1924, 22 December.

Radjabov, K. K. 2005. Voorujennoe dvijenie v Turkestanskom krae protiv sovetskogo rejima (1918- 1924 gg.). (Armed movement in Turkestan region against the Soviet regime (19181924). Abstract of a doctoral dissertation. Tashkent: Institut istorii Akademii nauk Uzbekistana (Institute of History, Academy of Sciences of Uzbekistan).

Rossiya. Polnoe geograficheskoe opisanie nashego Otechestva. Nastol'naya i dorojnaya kniga. Pod redaktsiey V.P.Semyonova-Tyan-Shanskogo. Tom devyatnadsatiy. Turkestanskiy kray. (Russia. The full geographic description of our motherland. Desk book and travel book. V.P.Semyonov-Tyan-Shanskii. Volume 19. Turkestan region). 1913. S-Peterburg: Izdanie A.F.Devriena.

Shigabdinov, R. N., and L. I. Jukova. 2002. 'Tatari'. (Tatars). In A. Ilkhamov (ed.), Etnicheskii atlas Uzbekistana. (Ethnic atlas of Uzbekistan). Istanbul: Open Society Institute Assistance Foundation Uzbekistan.

Tsentral'niy Gosudarstvenniy Arxiv Respubliki Uzbekistan (TsGA RUz) (Central State Archive of Uzbekistan), a: fond 1, opis 2, delo 8, list 144. 
- b: fond I-19, opis 1, delo 9829, list 8 .

- c: fond 36, opis 1, delo 21, list 4.

- d: fond 35, opis 1, delo 21, list 16.

- e: delo 99, list 5 .

- f: delo 143, list 30.

- g: list 22.

- h: fond 36, opis 1, delo 143, list 32.

- i: fond P.-85, opis 1, delo 6633, list 164.

- j: fond 36, opis 1, delo 143, list 43.

- k: list 31.

- 1: fond P-86, opis 1, delo 2222, list 50.

- m: fond P-34, opis 1, delo 2232, list 8.

- n: fond P-85, opis 1, delo 6633, list 164.

- o: fond P-34, opis 1, delo 356, list 626.

- p: fond P-86, opis 1, delo 2110, list 38.

- q: delo 8018, list 4.

Tursunov, Kh. T. 1957. Obrazovanie Uzbekskoy Sovetskoy Sotsialisticheskoy Respubliki. (The formation of the Uzbek Soviet Socialist Republic). Tashkent: Izdatelstvo Akademii Nauk Uzbekskoi SSR.

Vareykis, I., and I. Zelenskiy. 1924. Natsional'no-gosudarstvennoe razmejevanie Sredney Azii. (National and state delimitation of Central Asia). Tashkent: Sredne-Aziatskoe Gosudarstvennoe Izdatelstvo.

Vdovin, A. I. 2002. 'Evolyutsiya natsionalnoi politiki SSSR. 1917-1941 gg'. (The evolution of national policy of USSR. 1917-1941). Vestnik Moskovskogo universiteta. (Moscow University Bulletin), Ser. 8. Istoriya. \# 3.

Vsesoyuznaya perepis' naseleniya 1926 goda. Tom XV. Uzbekskaya SSR. Narodnost. Rodnoy yazyk. Vozrast. Gramotnost. (All-Union census of population of 1926. Volume 15. Uzbek SSR. Nationality. Native language. Age. Literacy). 1926. Moscow.

Zarubin, I. I. 1925. Spisok narodnostey Turkestanskogo kraya. (The list of nationalities of the Turkestan region). Leningrad: Izdatelstvo Rossiyskaoi Akademii Nauk. 